\title{
PERBANDINGAN MODEL GARCH SIMETRIS DAN ASIMETRIS PADA DATA KURS HARIAN ${ }^{*}$
}

\author{
Isna Shofia Mubarokah ${ }^{1}$, Anwar Fitrianto ${ }^{2 \ddagger}$, and Farit M Afendi ${ }^{3}$
}

\author{
1Department of Statistics, IPB University, Indonesia, isna_shofia@apps.ipb.ac.id \\ 2Department of Statistics, IPB University, Indonesia, anwarstat@gmail.com \\ ${ }^{3}$ Department of Statistics, IPB University, Indonesia, fmafendi@apps.ipb.ac.id \\ ‡corresponding author
}

Indonesian Journal of Statistics and Its Applications (elSSN:2599-0802)

Vol 4 No 4 (2020), 627 - 637

Copyright (C 2020 Isna Shofia Mubarokah, Anwar Fitrianto, and Farit M Afendi. This is an open-access article distributed under the Creative Commons Attribution License, which permits unrestricted use, distribution, and reproduction in any medium, provided the original work is properly cited.

\begin{abstract}
ARCH and GARCH models are widely used in financial data to describe its volatility pattern. The models assume the positive and negative return residual gives the same or symmetric influence on its volatility. However, in reality, this assumption is frequently violated, which is called heteroscedasticity. Therefore, to deal with heteroscedasticity and asymmetric data, the asymmetric GARCH models, which are EGARCH and GJRGARCH models are used. This research aims to compare the models between symmetric and asymmetric GARCH to make financial data modeling. It uses daily data on three foreign exchange rates for IDR including IDR/CNY, IDR/JPY, and IDR/USD. The data series to be used here are from January 4, 2016, to January 20, 2020. This research method is started by selecting the best mean model for each data. Based on the best mean model, then modeling the mean and variance function are simultaneously conducted using the GARCH model. To test whether there was an asymmetric effect on the data, a Lagrange multiplier test was applied on the residuals of the GARCH model. The results show that the asymmetric effect was found in the IDR/CNY and IDR/JPY exchange rates. To overcome this asymmetric effect, EGARCH and GJR-GARCH model were applied to the two exchange rates. Then the two models are compared to find out which volatility model is better. Using AIC and BIC we find EGARCH as the best model for IDR/CNY exchange rates daily return and GJR-GARCH as the best model for IDR/JPY exchange rates daily return.
\end{abstract}

Keywords: asymmetric GARCH, EGARCH, GJR-GARCH, return, volatility.

\footnotetext{
`Received Sep 2020; Accepted Des 2020; Published online on Des 2020
} 


\section{Pendahuluan}

Salah satu pemodelan yang dapat digunakan untuk data deret waktu adalah model Autoregressive Integrated Moving Average (ARIMA). Model ini mengasumsikan bahwa volatilitas data adalah konstan. Namun pada data finansial, banyak terdapat kasus data dengan volatilitas yang tidak konstan. Volatilitas yang tidak konstan inilah yang akan menyebabkan masalah heteroskedastik pada data. Oleh karena itu diperlukan pemodelan yang dapat mengakomodasi permasalahan heteroskedastik pada data. Salah satu pemodelan yang dapat digunakan adalah model Generalized Autoregressive Conditional Heteroscedasticity (GARCH). Model GARCH memiliki karakteristik respon volatilitas terhadap suatu guncangan adalah sama, baik guncangan positif maupun guncangan negatif.

Pada data finansial, tidak semua data memiliki karakteristik respon volatilitas yang sama terhadap suatu guncangan. Terdapat beberapa data finansial yang memiliki perbedaan besarnya perubahan pada volatilitas ketika terjadi pergerakan nilai return yang disebut dengan pengaruh keasimetrisan, atau sering juga disebut leverage effect. Keasimetrisan yang terjadi dapat berupa korelasi negatif maupun positif antara nilai return sekarang dengan volatilitas yang akan datang. Korelasi negatif antara nilai return dengan perubahan volatilitasnya, berarti kecenderungan volatilitas menurun ketika return naik dan volatilitas meningkat ketika return melemah. Keberadaan efek asimetris pada data finansial menyebabkan model GARCH menjadi tidak tepat digunakan untuk menduga model. Oleh karena itu diperlukan pemodelan yang dapat mengakomodir efek asimetris yang muncul pada sebagian besar data finansial. Model yang dapat digunakan adalah model GARCH asimetris. Terdapat beberapa model GARCH asimetris yang dapat mengatasi efek asimetris pada data, di antaranya adalah Exponential GARCH (EGARCH) dan Glosten, Jagannathan and Runkle GARCH (GJR-GARCH). Oleh karena itu, penelitian ini bertujuan untuk membandingkan antara model GARCH dengan model GARCH asimetris yang terdiri dari EGARCH dan GJR-GARCH dalam memodelkan return data finansial.

Terdapat beberapa penelitian mengenai model deret waktu asimetris yang telah dilakukan, diantaranya adalah (Dutta, 2014) yang melakukan perbandingan antara model GARCH dengan model GARCH asimetris. Dalam penelitian tersebut dilakukan perbandingan antara model GARCH, EGARCH, dan GJR-GARCH untuk memodelkan data nilai tukar Dollar US dengan Yen Jepang. Model EGARCH dan GJR-GARCH digunakan untuk mengakomodir pengaruh yang tidak sama antara guncangan positif dan guncangan negatif terhadap volatilitas. Untuk mengatasi efek asimetris ini, (Karmakar, 2017) juga menggunakan model GARCH asimetris untuk memodelkan nilai tukar Rupee terhadap 5 mata uang asing, yaitu USD, SF, JPY, GBP, dan EURO.

\section{Metodologi}

\subsection{Data}

Data yang digunakan dalam penelitian adalah data sekunder yang dapat diakses pada situs Bank Indonesia. Data yang diambil berupa data harian nilai tukar mata uang (kurs) Indonesia terhadap 3 negara lain berupa data kurs jual dan kurs beli. Data 
yang diambil adalah nilai kurs selama periode 4 Januari 2016 hingga 20 Januari 2020 yang berjumlah 1233 data untuk masing-masing kurs. Dalam penelitian ini, kurs yang digunakan terdiri dari kurs Rupiah terhadap Yuan Cina (IDR/CNY), kurs Rupiah terhadap Dollar Amerika (IDR/USD) dan kurs Rupiah terhadap Yen jepang (IDR/JPY).

Untuk menduga nilai $\mathrm{VaR}$ akan digunakan data continuous return dari kurs tengah ketiga nilai tukar Rupiah. Sedangkan bobot yang digunakan dalam pembentukan portofolio pada penelitian ini diasumsikan sama untuk setiap saham, yaitu $1 / n$. Dengan $\mathrm{n}$ adalah banyaknya saham dalam portofolio.

\subsection{Metode Penelitian}

Analisis data dilakukan menggunakan perangkat lunak $\mathrm{R}$. Langkah-langkah analisis data yang dilakukan dalam penelitian ini adalah:

1. Menghitung kurs tengah untuk ketiga saham dengan rumus menurut (Ekananda, 2014) sebagai berikut:

$$
\text { kurs tengah }=\frac{\text { kurs jual }+ \text { kurs beli }}{2}
$$

kurs jual dan kurs beli merupakan nilai tukar Rupiah yang diperoleh dari laman Bank Indonesia.

2. Menghitung return kurs tengah untuk ketiga saham menggunakan persamaan:

$$
r_{t}=\ln \left(1+R_{t}\right)=\ln \frac{P_{t}}{P_{t-1}}=\ln P_{t}-\ln P_{t-1}
$$

dengan $P_{t}$ adalah nilai kurs tengah pada waktu ke-t dan $P_{t-1}$ adalah nilai kurs tengah pada waktu ke- $(t-1)$.

3. Melakukan eksplorasi dan mengidentifikasi karakteristik data return kurs tengah.

4. Melakukan pendugaan parameter model untuk masing-masing kurs

a. Menentukan model rataan untuk masing-masing data.

b. Melakukan pengujian efek ARCH menggunakan uji ARCH-Lagrange Multiplier (ARCH-LM) terhadap galat dari model rataan untuk mengetahui ada atau tidaknya heteroskedastisitas.

c. Jika terdapat efek ARCH maka akan dilakukan pemodelan data menggunakan GARCH.

d. Melakukan pengujian efek asimetris pada galat model GARCH. Pengujian dapat dilakukan dengan cara melihat korelasi antara $\varepsilon_{t}^{2}$ (galat kuadrat) dengan $\varepsilon_{t}$ (lag galat) dengan menggunakan korelasi silang. Menurut (Bauwens et al., 2012) adanya efek asimetris ditandai dengan korelasi yang tidak sama dengan nol.

e. Jika tidak terdapat efek asimetris maka akan dilakukan pemodelan menggunakan model GARCH. Namun jika terdapat efek asimetris maka akan dilakukan pemodelan data menggunakan Asymmetric GARCH menggunaka EGARCH dan GJR-GARCH.

5. Menentukan model terbaik untuk masing-masing kurs berdasarkan Akaike Information Criterion (AIC) dan Bayesian Information Criterion (BIC) terkecil. Dengan persamaan menurut (Tsay, 2005) sebagai berikut:

$$
A I C=-2 \log L+2 k
$$




$$
B I C=-2 \log L+k \log n
$$

dalam hal ini $\mathrm{L}$ menyatakan fungsi likelihood, $k$ menyatakan banyaknya parameter, dan $n$ menyatakan banyaknya data.

\section{Hasil dan Pembahasan}

\subsection{Eksplorasi Data}

Data yang digunakan adalah data nilai kurs tengah rupiah terhadap 3 nilai tukar mata uang negara lain yang terdiri dari 1233 data. Gambar 1 merupakan plot data untuk ketiga kurs dengan sumbu $X$ menyatakan waktu yang dimulai dari indeks 1 pada tanggal 4 Januari 2016 hinggal indeks 1233 pada tanggal 20 Januari 2020. Plot pada Gambar 1 menunjukkan bahwa data kurs tengah untuk ketiga nilai tukar rupiah sangat berfluktuatif. Ketika nilai tukar rupiah terhadap suatu mata uang semakin naik atau tinggi, maka mata uang rupiah melemah. Hal ini berarti, kenaikan yang ditunjukkan plot pada Gambar 1 menunjukkan pelemahan nilai rupiah terhadap nilai tukar mata uang asing. Sebaliknya, apabila terlihat penurunan yang ditunjukkan plot pada Gambar 1 menunjukkan nilai rupiah terhadap mata uang asing sedang menguat.

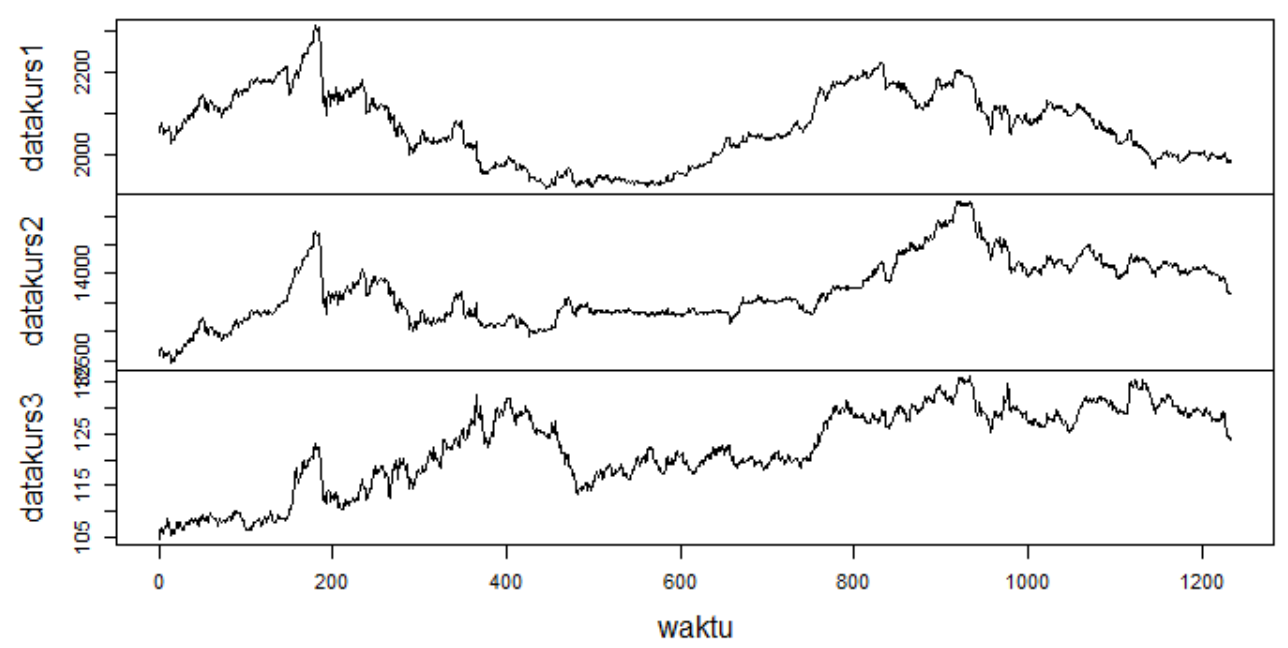

Gambar 1: Plot nilai kurs tengah.

Berdasarkan data kurs tengah, dihitung return kurs tengah untuk masing-masing nilai tukar rupiah menggunakan rumus pada Persamaan 1. Sehingga dihasilkan 1232 data return untuk masing-masing nilai tukar rupiah yang ditunjukkan pada Gambar 2. Sama halnya dengan Gambar 1, Gambar 2 merupakan plot untuk ketiga kurs dengan sumbu X menyatakan waktu yang dimulai dari indeks 1 pada tanggal 4 Januari 2016 hinggal indeks 1233 pada tanggal 20 Januari 2020. Gambar 2 menunjukkan adanya fluktuasi data yang relatif tinggi pada suatu waktu dan terjadi kecenderungan yang sama dalam kurun waktu selanjutnya. Fenomena ini disebut dengan volatility clustering yang mengindikasikan adanya heteroskedastisitas pada data. 


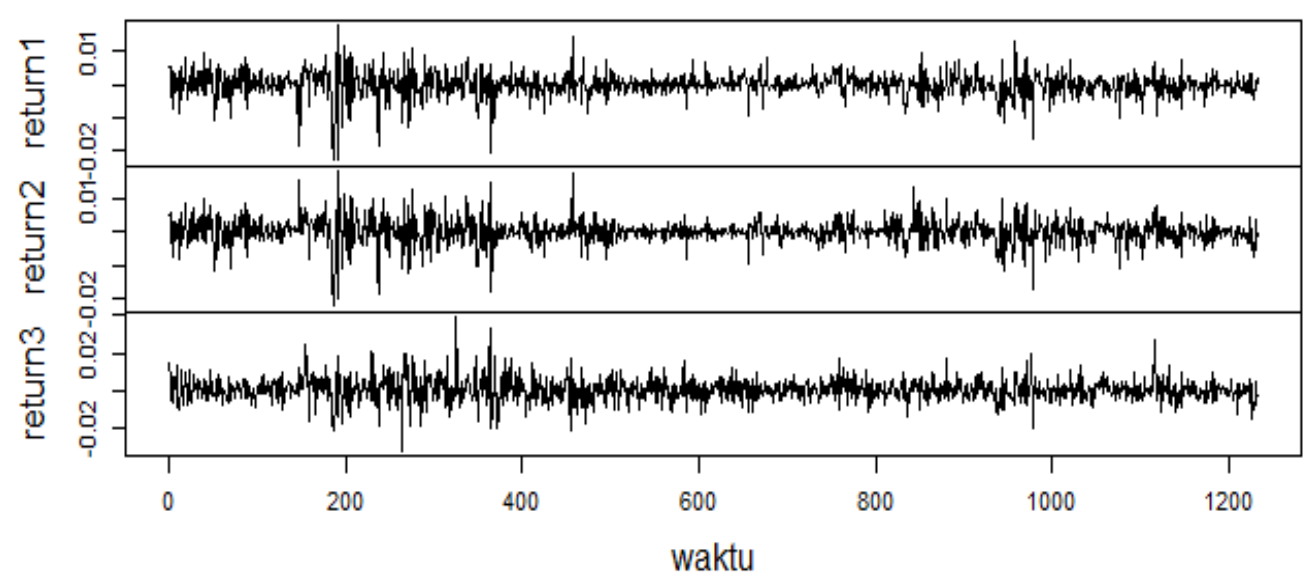

Gambar 2: Plot data return kurs tengah

Setelah melihat pola sebaran data, analisis statistika deskriptif juga dilakukan untuk melihat karakteristik data return masing-masing kurs. Hasil statistika deskriptif dari data return untuk masing-masing kurs tengah dapat dilihat pada Tabel 1.

Tabel 1: Statistika deskriptif data return kurs 1, kurs 2, dan kurs 3.

\begin{tabular}{lcccccc}
\hline Kurs & Minimum & Maksimum & Rataan & $\begin{array}{c}\text { Simpangan } \\
\text { baku }\end{array}$ & Skewness & Kurtosis \\
\hline $\begin{array}{l}\text { IDR/CNY } \\
\text { (kurs 1) }\end{array}$ & -0.0228 & 0.0178 & $\begin{array}{c}2.7330 \times 10^{-} \\
5\end{array}$ & 0.0038 & -0.9097 & 5.2503 \\
& & & & & \\
IDR/USD & -0.0223 & 0.0183 & $\begin{array}{c}6.5560 \\
\times 10^{-5}\end{array}$ & 0.0040 & -0.5556 & 4.3917 \\
$\begin{array}{l}\text { (kurs 2) } \\
\text { IDR/JPY } \\
\text { (kurs 3) }\end{array}$ & -0.0330 & 0.0395 & $\begin{array}{c}1.3684 \\
\times 10^{-5}\end{array}$ & 0.0064 & 0.2237 & 3.1178 \\
\hline
\end{tabular}

Jika dilihat pada Tabel 1, return 1 dan return 2 mempunyai nilai kemenjuluran yang negatif (left skewed), yang berarti bahwa kedua return ini mempunyai sebaran dengan bentuk kurva menjulur ke kiri, yang disebabkan oleh terdapatnya beberapa data ekstrim pada sebaran data ekor sebelah kiri (data-data kecil). Sebaliknya, kurs 3 mempunyai nilai kemenjuluran yang positif (right skewed), yang menunjukkan bahwa return 3 mempunyai sebaran dengan bentuk kurva menjulur ke kanan, atau dengan kata lain terdapat beberapa data ektrim pada sebaran data ekor sebelah kanan (datadata besar).

Selain nilai skewness, sebaran data juga dapat ditinjau dari nilai kurtosis (keruncingan). Apabila dilihat dari Tabel 3, semua kurs memiliki nilai keruncingan lebih dari 3, yaitu 5.2503 untuk kurs 1, 4.3917 untuk kurs 2, dan 3.1178 untuk kurs 3. Hal ini menunjukkan bahwa ketiga return ini memiliki bentuk kurva sebaran yang leptokurtik (meruncing) dan mengindikasikan bahwa sebaran data ketiga kurs memiliki pengaruh efek ARCH.

Informasi keruncingan dan kemenjuluran tersebut dapat mengindikasikan bahwa data return tidak mengikuti sebaran normal. Sebuah data diakatakan berdistribusi 
normal apabila memiliki nilai kemenjuluran sama dengan nol dan keruncingan sama dengan tiga. Melalui informasi ini, akan dilakukan uji lanjut untuk melihat keberadaan pengaruh efek ARCH pada masing-masing data kurs.

\subsection{Pendugaan Model Rataan Awal}

Pada pemodelan GARCH, terlebih dahulu akan dilakukan pemodelan terhadap rataan dari data. Pemodelan ini dapat ditentukan berdasarkan plot ACF serta PACF dari masing-masing data return. Berdasarkan plot ACF dan PACF seperti yang ditampilkan pada Gambar 3, untuk masing-masing return dapat dilihat bahwa tidak ada lag yang signifikan pada orde-order awal. Hal ini menunjukkan bahwa model rataan yang sesuai untuk ketiga return adalah model konstan yang memenuhi persamaan $r_{t}=\mu+\varepsilon_{t}$ dengan $r_{t}=$ return dari kurs, $\mu$ = rataan dari kurs, dan $\varepsilon_{t}=$ galat pada waktu ke $t$.
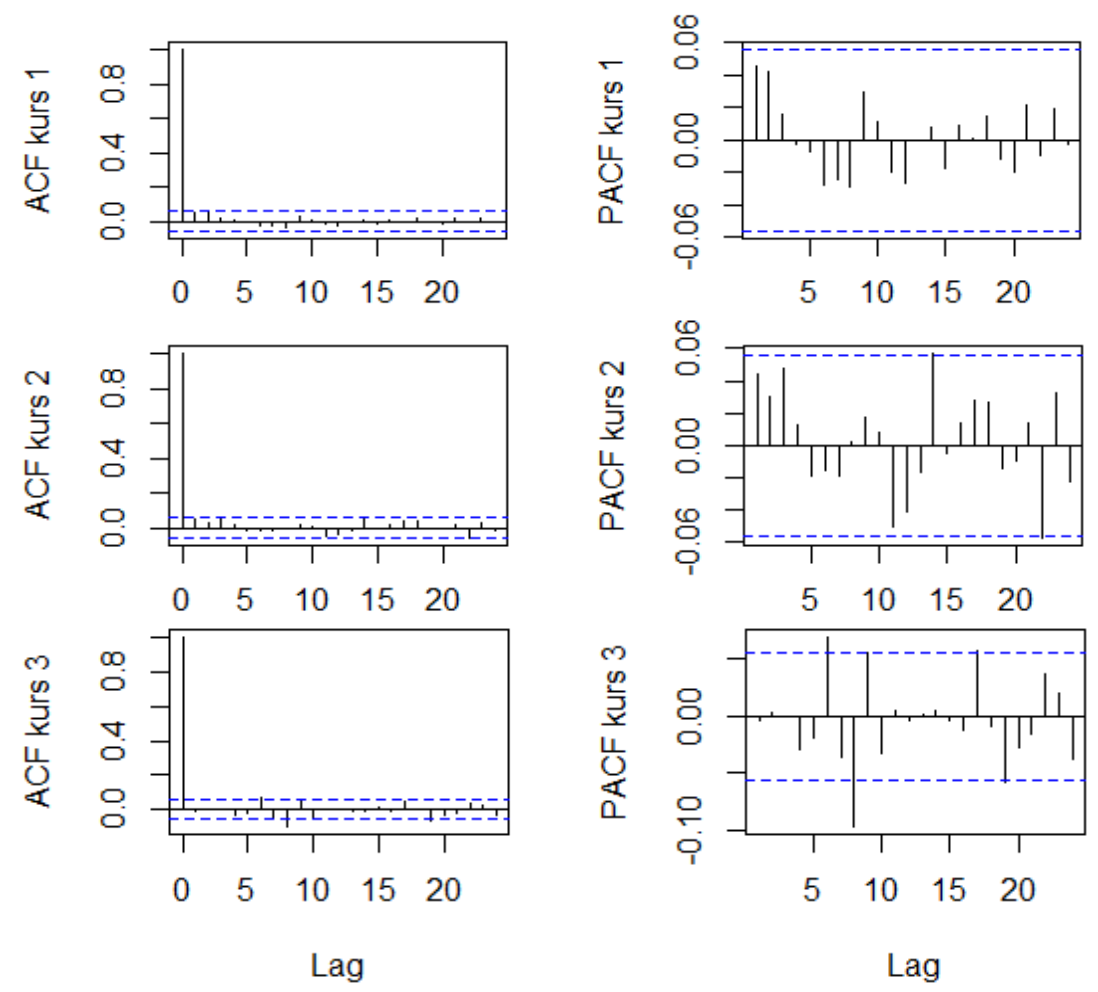

Gambar 3: Plot ACF dan PACF return kurs 1, kurs 2, dan kurs 3.

Untuk melihat apakah terdapat heteroskedastisitas pada sisaan model rataan, dilakukan uji ARCH Lagrange Multiplier (ARCH LM).

Tabel 2: Hasil nilai-p uji LM kurs 1, kurs 2, dan kurs 3.

\begin{tabular}{lcccc}
\hline \multirow{2}{*}{ Kurs } & \multicolumn{4}{c}{ Nilai-p } \\
\cline { 2 - 5 } & Lag 1 & Lag 6 & Lag 12 & Lag 24 \\
\hline Kurs 1 & 0.000 & 0.000 & 0.000 & 0.000 \\
Kurs 2 & 0.000 & 0.000 & 0.000 & 0.000 \\
Kurs 3 & $4.887 \times 10^{-9}$ & $5.099 \times 10^{-12}$ & $6.769 \times 10^{-12}$ & $4.065 \times 10^{-9}$ \\
\hline
\end{tabular}

Berdasarkan Tabel 2 dapat dilihat bahwa nilai-p uji LM untuk ketiga kurs hingga lag 
ke 24 adalah kurang dari taraf nyata, yaitu $5 \%(0,05)$. Sehingga dapat disimpulkan bahwa dalam sisaan terdapat heteroskedastisitas, suatu keadaan yang belum dapat diatasi oleh model konstan. Heteroskedastisitas pada sisaan model ini dapat diatasi menggunakan model ARCH apabila sisaan model rataan mengindikasikan proses short memory, yaitu hanya terdapat $q$ buah kuadrat sisaan terbaru yang digunakan untuk menduga perubahan ragam. Proses short memory ini ditandai dengan hanya nilai-p yang signifikan pada lag-lag awal. Namun, apabila dilihat pada Tabel 2 semua nilai-p signifikan hingga lag ke-24, hal ini berarti bahwa untuk kurs 1, kurs 2, dan kurs 3 mengindikasikan proses long memory. Adanya indikasi proses long memory ini membuat penggunaan model ARCH menjadi kurang tepat. Sehingga pemodelan untuk ragam bersyarat yang dilakukan adalah pemodelan $\mathrm{GARCH}$.

\subsection{Pendugaan Model GARCH}

Pemodelan GARCH dilakukan secara simultan dengan model rataan yang telah terpilih pada sub bab sebelumnya. Menurut (Anisa \& Himawan, 2018), belum terdapat metode yang langsung bisa menentukan seberapa besar orde pada model GARCH, melainkan dengan memilih bentuk yang paling sederhana. Oleh karena itu, pendugaan model GARCH ini dibatasi hanya pada model GARCH dengan ordo $(1,1)$.

Tabel 3: Hasil pendugaan parameter model GARCH.

\begin{tabular}{ccccccc}
\hline \multirow{2}{*}{ parameter } & \multicolumn{2}{c}{ Kurs 1 } & \multicolumn{2}{c}{ Kurs 2 } & \multicolumn{2}{c}{ Kurs 3 } \\
\cline { 2 - 7 } & Koefisien & Nilai-p & Koefisien & Nilai-p & Koefisien & Nilai-p \\
\hline $\boldsymbol{\mu}$ & 0.0002 & $0.0342^{*}$ & 0.0001 & 0.0640 & 0.0001 & 0.5592 \\
$\boldsymbol{\alpha}_{\boldsymbol{0}}$ & 0.0000 & 0.5874 & 0.0000 & 0.7534 & 0.0000 & 0.4694 \\
$\boldsymbol{\alpha}_{\boldsymbol{1}}$ & 0.0980 & $0.0000^{*}$ & 0.1718 & $0.0001^{*}$ & 0.0980 & $0.0121^{*}$ \\
$\boldsymbol{\beta}$ & 0.8897 & $0.0000^{*}$ & 0.8272 & $0.0000^{*}$ & 0.8897 & $0.0000^{*}$ \\
$\boldsymbol{v}$ & 4.6462 & $0.0000^{*}$ & 4.7160 & $0.0000^{*}$ & 4.6462 & $0.0000^{*}$ \\
\hline
\end{tabular}

*signifikan terhadap nilai $\alpha=5 \%$

Pada Tabel 3 dapat dilihat hasil pendugaan parameter model GARCH untuk masing-masing kurs. berdasarkan nilai-p yang dihasilkan oleh setiap hasil dugaan parameter, terdapat beberapa parameter yang memiliki nilai-p lebih dari 0.05 , artinya parameter-parameter tersebut tidak signifikan pada model. Namun karena pertimbangan praktis akan pentingnya semua parameter dalam model tersebut, maka parameter tersebut akan tetap dumasukkan ke dalam model dan nilai-p setiap dugaan parameter ini tidak menjadi pertimbangan untuk memilih model terbaik.

Model GARCH yang telah terbentuk dapat mengatasi masalah heteroskedastisitas pada data, namun model tersebut tidak dapat mengakomodir adanya efek asimetris pada return masing-masing kurs. Faktanya tidak semua data deret waktu mempunyai sifat simetris terhadap volatilitasnya. Oleh karena itu akan dilakukan uji apakah terdapat efek asimetris pada volatilitas model GARCH. Menurut Kumar \& Maheswaran (2012) dan Engle \& Ng (1993) mengajukan empat uji efek asimetris untuk mengetahui adanya efek asimetris pada data dengan hipotesis nol tidak terdapat efek asimetris pada volatilitas model. Jika terdapat keasimetrisan pada volatilitas model, maka akan dilakukan pemodelan GARCH asimetris. Dalam kajian ini, diperoleh hasil uji efek asimetris untuk ketiga kurs disajikan pada Tabel 4. 
Tabel 4: Hasil nilai-p uji efek asimetris kurs 1, kurs 2, dan kurs 3.

\begin{tabular}{lcccc}
\hline \multirow{2}{*}{ Kurs } & \multicolumn{4}{c}{ Nilai-p } \\
\cline { 2 - 5 } & $\begin{array}{c}\text { Sign } \\
\text { bias }\end{array}$ & $\begin{array}{c}\text { Negative sign } \\
\text { bias }\end{array}$ & $\begin{array}{c}\text { Positive sign } \\
\text { bias }\end{array}$ & Joint effect \\
\hline Kurs 1 & 0.06316 & $0.01549^{*}$ & 0.29492 & 0.06989 \\
Kurs 2 & 0.28840 & 0.43050 & 0.23340 & 0.56090 \\
Kurs 3 & $0.02092^{*}$ & 0.09435 & 0.05127 & 0.07116 \\
\hline
\end{tabular}

*signifikan terhadap nilai $\alpha=5 \%$

Berdasarkan hasil uji pada Tabel 4, dapat dilihat bahwa hasil uji efek asimetris untuk kurs 2 tak tolak hipotesis nol, karena memiliki nilai-p lebih dari $\alpha=5 \%$. Oleh karena itu kurs 2 akan tetap dimodelkan menggunakan GARCH. Akan tetapi, pada kurs 1 dan kurs 3 menunjukkan hasil tolak hipotesis nol karena memiliki nilai-p kurang dari 0.05. Sehingga untuk kurs 1 dan kurs 3 dimodelkan dengan $\mathrm{GARCH}$ asimetris, yaitu EGARCH dan GJR-GARCH.

\subsection{Pendugaan Model Asimetris GARCH}

Dalam penelitian ini digunakan dua model GARCH asimetris, yaitu EGARCH dan GJRGARCH. Berdasarkan hasil pemodelan dari model EGARCH dan GJR-GARCH tersebut dipilih model yang terbaik untuk masing-masing kurs 1 dan kurs 3 berdasarkan nilai AIC terkecil.

Tabel 5: Hasil pendugaan parameter model GARCH asimetris Kurs 1.

\begin{tabular}{crrrrrrrr}
\hline \multirow{2}{*}{ Parameter } & \multicolumn{3}{c}{ Model EGARCH } & \multicolumn{4}{c}{ Model GJR-GARCH } \\
\cline { 2 - 8 } & Koefisien & Nilai-p & AIC & BIC & Koefisien & Nilai-p & AIC & BIC \\
\hline $\boldsymbol{\mu}$ & 0.0002 & $0.0203^{*}$ & -8.6267 & -8.6018 & 0,0002 & $0.0297^{*}$ & -8.6250 & -8.6001 \\
$\boldsymbol{\omega}$ & -0.3278 & $0.0000^{*}$ & & & 0,0000 & 0.5524 & & \\
$\boldsymbol{\alpha}_{\boldsymbol{1}}$ & -0.0192 & 0.3691. & & & 0,0912 & $0.0000^{*}$ & \\
$\boldsymbol{\beta}_{\boldsymbol{1}}$ & 0.9713 & $0.0000^{*}$ & & & 0,8900 & $0.0000^{*}$ & \\
$\boldsymbol{\gamma}_{\boldsymbol{1}}$ & 0.2238 & $0.0000^{*}$ & & & 0,0110 & 0.7088 & \\
$\boldsymbol{v}$ & 4.5934 & $0.0000^{*}$ & & 4,6508 & $0.0000^{*}$ & \\
\hline
\end{tabular}

*signifikan terhadap nilai $\alpha=5 \%$

Tabel 6: Hasil pendugaan parameter model GARCH asimetris Kurs 3.

\begin{tabular}{crrrrrrrr}
\hline \multirow{2}{*}{ Parameter } & \multicolumn{3}{c}{ Model EGARCH } & \multicolumn{5}{c}{ Model GJR-GARCH } \\
\cline { 2 - 8 } & Koefisien & Nilai-p & AIC & BIC & Koefisien & Nilai-p & AIC & BIC \\
\hline $\boldsymbol{\mu}$ & 0,0002 & 0.2915 & -7.4356 & -7.4106 & 0.0001 & 0.3870 & -7.4419 & -7.4169 \\
$\boldsymbol{\omega}$ & -0.2573 & $0.0000^{*}$ & & & 0.0000 & 0.6101 & & \\
$\boldsymbol{\alpha}_{\boldsymbol{1}}$ & 0.0487 & $0.0103^{*}$ & & & 0.1014 & $0.0401^{*}$ & & \\
$\boldsymbol{\beta}_{\mathbf{1}}$ & 0.9750 & $0.0000^{*}$ & & & 0.8986 & $0.0000^{*}$ & & \\
$\boldsymbol{\gamma}_{\boldsymbol{1}}$ & 0.1498 & $0.0000^{*}$ & & & -0.0553 & $0.0017^{*}$ & & \\
$\boldsymbol{v}$ & 6.7516 & $0.0000^{*}$ & & & 6.9330 & $0.0000^{*}$ & & \\
\hline
\end{tabular}

\footnotetext{
*signifikan terhadap nilai $\alpha=5 \%$
} 
Pada Tabel 5 dan Tabel 6 dapat dilihat hasil pendugaan parameter model GARCH asimetris, yaitu model EGARCH dan GJR-GARCH. Sama halnya dengan model $\mathrm{GARCH}$, pada model GARCH asimetris ini juga terdapat beberapa parameter yang memiliki nilai-p lebih dari 0.05 , artinya parameter-parameter tersebut tidak signifikan untuk masuk model. Namun karena pertimbangan praktis akan pentingnya semua parameter dalam model tersebut, maka parameter tersebut akan tetap dimasukkan ke dalam model dan nilai-p setiap dugaan parameter ini tidak menjadi pertimbangan untuk memilih model terbaik. Pemilihan model terbaik untuk kurs 1 dan kurs 3 ini menggunakan nilai AIC yang dihasilkan oleh masing-masing model. Berdasarkan nilai AIC terkecil untuk masing-masing model pada Kurs 1 dan Kurs 3, maka diperoleh hasil bahwa model GARCH asimetris terbaik untuk Kurs 1 adalah model EGARCH, dan model GARCH asimetris terbaik untuk Kurs 3 adalah model GJR-GARCH.

\subsection{Model Marginal Terbaik}

Berdasarkan semua pendugaan model yang telah dilakukan, baik model GARCH maupun Model GARCH asimetris serta kriteria pemilihan model, maka model terbaik untuk masing-masing kurs dapat dituliskan seperti pada Tabel 7.

Tabel 7: Hasil model marginal terbaik.

\begin{tabular}{lllr}
\hline Data & Model terbaik & Fungsi rataan & Fungsi ragam \\
\hline Kurs 1 & EGARCH & $Y 1_{t}=0.000148+\varepsilon 1_{t} \ln \left(\sigma 1_{t}^{2}\right)=-0.3278-0.0192 z 1_{t-1}+$ \\
& & & $0.9713 \log \left(\sigma_{t-1}^{2}\right)+0.2238 \mid z$ \\
Kurs 2 & GARCH & $Y 2_{t}=0.000128+\varepsilon 2_{t}$ & $\sigma 2_{t}^{2}=0.0000+0.1718 \varepsilon 2_{t-1}^{2}+$ \\
& & & $0.8272 \sigma 2_{t-1}^{2}$ \\
Kurs 3 & GJR-GARCH & $Y 3_{t}=0.000130+\varepsilon 3_{t}$ & $\sigma 3_{t}^{2}=0.0001+0.0000 \varepsilon 3_{t-1}^{2}+$ \\
& & & $0.8986 \sigma 3_{t-1}^{2}-0.0553 D_{t-1}$ \\
\hline
\end{tabular}

Pada Tabel 7 dapat dilihat bahwa model terbaik untuk masing-masing kurs berbeda. Model terbaik untuk kurs 2 adalah model $\mathrm{GARCH}$, artinya nilai tukar Rupiah terhadap Dollar hari ini dipengaruhi oleh nilai sisaan pada periode yang sama, sedangkan ragam bersyaratnya merupakan fungsi dari sisaan dan ragam bersyarat periode sebelumnya.

Sedangkan model terbaik yang diperoleh untuk kurs 1 dan kurs 3 adalah model GARCH asimetris, yaitu model EGARCH untuk kurs 1 dan model GJR-GARCH untuk kurs 3. Artinya, nilai tukar Rupiah terhadap Yuan Cina dan Yen Jepang dipengaruhi oleh nilai sisaan pada periode yang sama. Berbeda dengan model GARCH yang membatasi nilai parameternya agar ragam bersyarat tidak bernilai negatif, pada model GARCH asimetris ini nilai parameternya tidak dibatasi baik negatif maupun positif, karena pada model EGARCH terdapat bentuk eksponensial sehinggal berapapun nilai koefisien parameternya maka nilai ragam bersyaratnya akan tetap positif. Sedangkan untuk model GJR-GARCH terdapat parameter $D_{t-1}$ yang merupakan peubah dummy. $D_{t-1}$ akan bernilai 1 apabila $\varepsilon_{t-j}$ negatif dan bernilai 0 jika $\varepsilon_{t-j}$ positif.

Hal lain yang perlu diperhatikan dalam model GARCH asimetris ini adalah nilai koefisien $\gamma$. Pada model EGARCH, Menurut (Angabini \& Wasiuzzaman, 2011) adanya 
efek leverage pada data dapat dilihat dari nilai koefisien parameter $\gamma$ yang bernilai negatif. Pada model terbaik kurs 1, diperoleh hasil pendugaan koefisien parameter $\gamma=$ 0.2238 , hal tersebut menandakan tidak terdapat efek leverage karena koefisien $\gamma$ bernilai positif. Sedangkan pada model GJR-GARCH, menurut (Dutta, 2014) adanya efek leverage pada data dapat dilihat dari nilai koefisien parameter $\gamma$ yang bernilai positif. Pada model terbaik kurs 3, diperoleh hasil pendugaan koefisien parameter $\gamma=$ -0.0553 hal tersebut menandakan tidak terdapat efek leverage karena koefisien $\gamma$ bernilai negatif.

\subsection{Diagnostik SIsaan Model Terbaik}

Setelah dipilih model terbaik untuk masing-masing return kurs, selanjutnya dilakukan uji diagnostik untuk melihat apakah model yang terbentuk tersebut telah memadai untuk digunakan. Diagnostik sisaan yang dilakukan adalah pengujian autokorelasi siaan, uji ARCH LM serta pengujian kenormalan sisaan dengan menggunakan uji Jarque-bera. Sisaan yang akan diuji adalah sisaan terstandarisasi.

Tabel 8: Hasil uji diagnostic.

\begin{tabular}{lcccccc}
\hline \multirow{2}{*}{ Kurs } & \multicolumn{2}{c}{ P-value uji weighted ljung-box } & \multicolumn{2}{c}{ P-value uji weighted LM ARCH } \\
\cline { 2 - 7 } & Lag[1] & Lag[5] & Lag[9] & Lag[3] & Lag[5] & Lag[7] \\
\hline Kurs 1 & 0,6044 & 0,8815 & 0,9751 & 0,6044 & 0,8815 & 0,9751 \\
Kurs 2 & 0,7640 & 0,7370 & 0,8917 & 0,3704 & 0,6316 & 0,8041 \\
Kurs 3 & 0,5731 & 0,7479 & 0,8912 & 0,3361 & 0,5703 & 0,7479 \\
\hline
\end{tabular}

Uji weighted ljung-box bertujuan untuk melihat apakah terdapat korelasi pada sisaan kuadrat dari model yang dihasilkan dengan $H_{0}$ : tidak terdapat korelasi pada sisaan model. Dari Tabel 6 dapat dilihat bahwa nilai $p$-value untuk semua lag yang diujikan, yaitu lag 1, lag 5, dan lag 9 lebih dari taraf nyata (5\%). Hal ini berarti bahwa sudah tidak terdapat korelasi pada sisaan dari model. Uji weighted $L M A R C H$ bertujuan untuk melihat keberadaan efek $\mathrm{ARCH} / \mathrm{GARCH}$ dengan hipotesis nol tidak terdapat efek ARCH/GARCH. Dari Tabel 6 dapat dilihat bahwa nilai $p$-value untuk semua lag yang diujikan bernilai lebih dari taraf nyata (5\%), sehingga dapat disimpulkan bahwa sudah tidak terdapat efek ARCH/GARCH. Untuk menguji kenormalan sisaan model, digunaka uji Jarque-bera. Nilai-p yang dihasilkan pada uji ini adalah sebesar $2 \times 10^{-16}$ untuk ketiga kurs dengan model terbaik dari masingmasing kurs, sehingga cukup bukti untuk tolak hipotesis nol. Sehingga dapat disimpulkan bahwa untuk ketiga kurs asumsi kenormalan sisaan belum terpenuhi. Adanya penyimpangan terhadap asumsi kenormalan sisaan ini merupakan indikasi bahwa data memiliki volatilitas yang sangat acak dan memiliki nilai-nilai yang ekstrim.

\section{Simpulan}

Berdasarkan pemodelan yang telah dilakukan, diperoleh kesimpulan bahwa model terbaik untuk masing-masing kurs tidak lah sama. Model terbaik untuk kurs 1 adalah model EGARCH, model terbaik untuk kurs 2 adalah model GARCH, sedangkan model terbaik untuk kurs 3 adalah GJR-GARCH. 


\section{Daftar Pustaka}

Angabini, A., \& Wasiuzzaman, S. (2011). GARCH Models and the Financial Crisis-A Study of the Malaysian. The International Jou-Rnal of Applied Economics and FinAnce Vol. 5 No, 3: 226-236.

Anisa, A., \& Himawan, H. (2018). Penggunaan GARCH dalam Pemodelan Data Nilai Tukar IDR terhadap USD. Jurnal Matematika, Statistika Dan Komputasi, 3(2): 6069.

Bauwens, L., Hafner, C. M., \& Laurent, S. (2012). Handbook of volatility models and their applications (Vol. 3). John Wiley \& Sons.

Dutta, A. (2014). Modelling volatility: symmetric or asymmetric garch models. Journal of Statistics: Advances in Theory and Applications, 12(2): 99-108.

Ekananda, M. (2014). Basic Econometrics for Research on Economics. Jakarta (ID): Mitra Wacana Media.

Engle, R. F., \& Ng, V. K. (1993). Measuring and testing the impact of news on volatility. The Journal of Finance, 48(5): 1749-1778.

Karmakar, M. (2017). Dependence structure and portfolio risk in Indian foreign exchange market: A GARCH-EVT-Copula approach. The Quarterly Review of Economics and Finance, 64: 275-291.

Kumar, D., \& Maheswaran, S. (2012). Modelling asymmetry and persistence under the impact of sudden changes in the volatility of the Indian stock market. IIMB Management Review, 24(3): 123-136.

Tsay, R. S. (2005). Analysis of financial time series (Vol. 543). John wiley \& sons. 